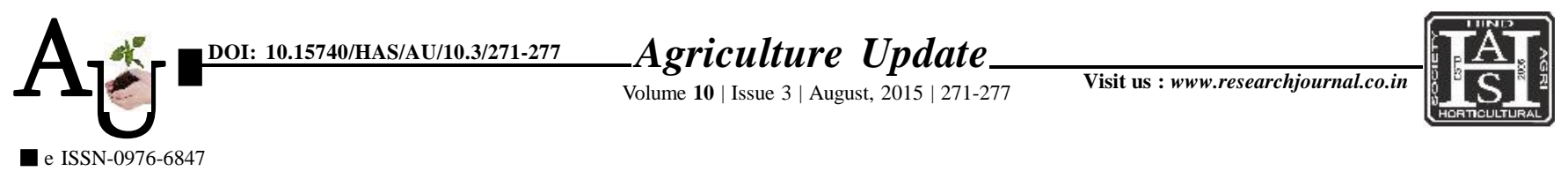

\title{
Research Article: Decomposition analysis and acreage response of soybean
}

\section{K.R. MANKAWADE, S.S. THAKARE, D.H. ULEMALE AND S.L. RATHOD}

Article Chronicle: Received :

16.07.2015;

Revised :

25.08.2015;

Accepted :

31.08.2015

KeY Words :

Soybean,

Decomposition,

Growth rate,

Instability

Author for correspondence :

\section{S.S. THAKARE}

Department of Agricultural Economics, Shri Shivaji Agriculture

College, AMRAVATI (M.S.)

INDIA

Email: drsandipthakare@ gmail.com

See end of the article for authors' affiliations
SUMMARY : In this study an attempt had been made to study the growth and instability of soybean in Amravati division. The study was based on secondary data on area, production and productivity of soybean, FHP and rainfall, collected from the various Government publications. The study revealed that compound growth rates for area, production and productivity of soybean was recorded positive. The growth rate for area, production and productivity was recorded high during period I. The coefficient of variation and coppock's instability index with regards to area (1.08 and 0.62$)$ productivity (2.00 and 1.62) were lowest in Akola and Amavati district, respectively, whereas production was recorded lowest co-efficient of variation and coppock's instability index in Akola district (0.86 and 0.48). At overall period, area effect, yield effect, and interaction effect do not show any influence on one another. The study also reveals that, the short run price elasticity were comparatively higher than the long run price elasticity in soybean, which indicated that the farmers were relatively market oriented in their decision in long run than in the short turn.

How to cite this article : Mankawade, K.R., Thakare, S.S., Ulemale, D.H. and Rathod, S.L. (2015). Decomposition analysis and acreage response of soybean. Agric. Update, 10(3): 271-277. 